\title{
The art of storytelling in Old Javanese prose as illustrated by the story of Ekalawya
}

\author{
WILLEM VAN DER MOLEN
}

\begin{abstract}
Scholarly attention for Old Javanese literature so far has mainly focused on poetry. The apparently simple nature of narrative prose texts, while making them excellent sources for linguistic and lexicographic research, at the same time denies them any literary value. In this article an impression is given of the art of storytelling in one Old Javanese prose story, taken from the Adiparwa of around A.D. 1000. Quite unexpectedly, a sophisticated tradition unfolds in which a rich variety of devices enables the storyteller to create a meaningful world of words.

KEYWORDS

Old Javanese; Mahabharata; prose; literary analysis.
\end{abstract}

\section{INTRODUCTION}

This article ${ }^{1}$ discusses an instance of narrative art in Old Javanese. My example is a written story, in prose, part of a larger text, with no title of its own. ${ }^{2}$ After the character it begins with we might call it "the story of Ekalawya". It is found in the first "book" (parwa) of the Old Javanese Mahabharata, the Adiparwa. Narrative art in Old Javanese prose texts is a hitherto neglected field. I know of one other article - but using a different example -, written by myself twenty years ago; see Van der Molen 1997 (footnote 3 hints at a possible explanation of this general neglect). It is by mere chance that I chose the Adiparwa for

1 This article is based on an unpublished paper read for the Oriental Faculty of the State University at St. Petersburg, 24 April 2003. I have profited very much from the remarks and suggestions made by Prof. S.O. Robson, also by Drs R.E. Jordaan and K.J.J. Korevaart. I wish to thank them all. I would also like to thank the anonymous reviewer, whose careful and supportive report made me rethink and reformulate several points.

2 I limit myself to the written text. Possible connections between the written text and performing arts (the shadow theatre, oral literature, the recitation of written texts) represent different topics with different questions that fall outside the scope of this article.

WILLEM VAN DER MOLEN was born in Leeuwarden, the Netherlands, in 1952. He studied Indonesian languages and literatures at Leiden University, where he took his doctoral degree in 1983. He is a senior researcher at the Royal Institute of Southeast Asian and Caribbean Studies in Leiden, the Netherlands, and Professor of Philology and Old Javanese at Universitas Indonesia, Depok, Indonesia. Willem van der Molen may be contacted at: molen@kitlv.nl. 
this occasion, especially the story of Ekalawya. Evidently, my findings cannot but be of a preliminary nature; only after research will have been widened to other texts will it become clear to what extent the narrative art of the story of Ekalawya stands for Old Javanese narrative art in general.

The dominant genre of Javanese literature before 1500 (called Old Javanese literature) was poetry of one special kind, the kakawin. Literary prose before 1500 does exist but is relatively rare. Its main representative is the Old Javanese rendering of the Sanskrit Mahabharata, one of the two famous epics of Indian soil. The Old Javanese version was created around A.D. 1000. Compared to the Sanskrit text it is incomplete, as only nine out of the eighteen books of the original were selected for Javanization. In the process, moreover, the text underwent a severe reduction. Nevertheless, the result is a fully-fledged work of art that deserves our attention. ${ }^{3}$

The Old Javanese Mahabharata marks a new step in the history of Javanese literature. The author or authors ventured on a creative experiment, namely the use of prose as a medium for literature. Until then, literature was equated with poetry (the Sanskrit Mahabharata is also in poetry). Another innovation introduced by the parwas was the invocation of the author's manggala, at the beginning of the text. Manggala means "a god or god-like person who is appealed to as having the power to bring the work to a successful conclusion" (Robson 1983: 310). As a literary device it is not attested before the parwas.

Since then - though perhaps not exclusively through the parwa tradition the stories of the Mahabharata became part and parcel of Javanese literature and culture. In this sense the parwas were a success. However, as an experiment in prose they were a failure. The use of prose as a literary medium did not take root; it was discontinued by later authors and as a consequence vanished from the literary scene, not to reappear before the middle of the nineteenth century (with the publication of Candranegara's Purwalelana in 1865-1866). The literary use of the manggala on the other hand met with approval; it was applied in all kakawins that were written after the parwa of the Mahabharata.

The Old Javanese Adiparwa, of which the story of Ekalawya forms part, is an entertaining text with a didactic overtone. It relates the adventures of the Pandawas and Korawas and several other heroes, at the same time addressing topics of religion, ethics, and social relationships from a Hindu point of view.

From the viewpoint of narrative technique the Old Javanese Adiparwa is a framestory. Its groundplan is simple enough. What makes it complicated is the length of the text, the multitude of stories and the embedding of new stories within stories that are already embedded themselves, while the main line is further interrupted by side-steps going back or forward in time. Fortunately, transparency is guarded by various devices, such as previews and genealogies,

3 This is not communis opinio. Research of the Old Javanese parwas is thwarted by two prejudices: 1. these texts are simple renderings of the original texts in Sanskrit, not susceptible to the label of literature; 2 . they are simply renderings of the original texts, that can only be fully understood by referring to the original texts. The second prejudice is annulled by the age-long but Sanskrit-free appreciation of the Old Javanese parwas in Java and Bali, while undoing the first prejudice is the aim of this article. 
laying out how the story will develop, or the formal division of the text into smaller units. Precisely how these and similar devices help to structure the Adiparwa is an interesting problem still waiting scholarly attention.

Here I want to address the problem of storytelling in the Adiparwa at its lowest narrative level, the short story. The story of Ekalawya needs less than one page in print. One could call it a "very short story". However, its tiny size is no impediment to its being divisible into even smaller parts. These smaller parts all contribute to the transparency of the construction; at the same time they point the way to our interpretation of the story. How this works is what I shall attempt to demonstrate in the next pages.

The Old Javanese text for my research is taken from Juynboll's edition of the Adiparwa of 1906. The appendices attached at the end of the article contain the Old Javanese text together with an English translation. I have printed the sentences one below the other and numbered them for the ease of reference, grouping them into clusters according to the divisions of the text. In the original edition they are of course presented as one continuous text.

\section{THE STORY OF EKALAWYA}

The story of Ekalawya is set during the youth of the Pandawas and Korawas, at a time when the cousins are still living more or less peacefully together in the palace at Hastina. Its wider context is the story of Drona, relating how he was born and grew up, and after a couple of adventures settled at the court of Hastina as the teacher of the princes. In the pages preceding our story we read that Drona trained the boys (and other princes from neighbouring countries attracted by Drona's fame) in the use of weapons. In particular Arjuna makes considerable progress, to the satisfaction of his teacher. Drona even proclaims him the best archer in the world.

At this point the story of Ekalawya begins. No sooner has Drona pronounced his judgement than the qualities of one Ekalawya seem to belie these words. It turns out that he was a self-appointed external student of Drona, whom Drona had completely forgotten about. Ekalawya had been denied access to Drona's lessons because of his low, non-Aryan descent. He then had made a replica of Drona - a picture or a statue; the word used can mean both - and had trained himself under the "supervision" of this replica, with the said outcome. Arjuna concludes that Drona has lied to him. Drona puts things straight by having Ekalawya cut off his right thumb, so that he cannot shoot anymore. Here the story ends; Ekalawya disappears from the Adiparwa.

A talented young man denied access to instruction on the basis of descent, betrayed by an envious fellow-student, and violently bereft of his prospects by a man who calls himself a teacher. What is the story of Ekalawya about?

Although it is possible to read the story as an early plea for equal opportunity or moral example I think it is something else that is at stake here. In the perspective of the narrator the wrong is on Ekalawya's side. The story is about order, that is the divine order of society as laid out by sacred tradition, manifesting itself through the dharma and powered by the ambition of a good karma. Ekalawya is 
undermining that order by applying for education that his background excludes him from, by pretending to be a pupil of Drona although he has been rejected, and by drawing from knowledge he is not allowed to possess.

Given the idea of dharma as the encompassing theme, the author of the Adiparwa in this story directs the attention of the reader to the question of how loyalty could collide with dharma. Two values that are basic to loyalty, devotion and honesty, are illustrated by the case of Ekalawya and Arjuna. How does the composition of the story support this interpretation? ${ }^{4}$

\section{NARRATIVE UNIT}

The story of Ekalawya forms a narrative unit within the story of Drona. The borders are drawn by linguistic means at the beginning and end:

beginning: Now there was a certain Ekalawya, the son of Hiranyadhanuh. end: $\quad$ For he was the swiftest one in the art of archery.

"Now there was a certain ..." is a formula used in the Adiparwa to introduce a new character or to start a new story. Usually, the name of the character introduced is followed by an extension like "the child of ..." or " who reigned in ...". The story of Drona, the frame story of our story, for example, begins with: "Now there was a certain Bharadwaja, the son of the reverend Werhaspati, the one who had been rejected by Dirgatama" (Juynboll 1906: 126). Other stories in and outside the story of Drona, including the Adiparwa itself, do something similar. In the case of Ekalawya, the hero is qualified by the extension "son of Hiranyadhanuh". There is no further explanation as to who Hiranyadhanuh is, also not in the wider context of the Adiparwa as a whole.

The end of a story does not have to be indicated explicitly in the Adiparwa. Often the "Now there was a certain ..." of the next story will do. The story of Ekalawya has a marked border of its own because it is embedded in a framestory; it is not followed by something new. The sentence it ends with recalls the initial situation, before Ekalawya entered the scene. In other words, it brings the reader back to the level of the frame story. We left the frame story at the point where Arjuna had been declared the best of archers by Drona:

My child Arjuna! There will never be your equal in archery. You are the best in it.

The story of Ekalawya ends with a reference to that claim:

He, then, was the swiftest one in the art of archery.

Surveying its contents, we find that the story of Ekalawya is divided into two smaller units or episodes. The sentence responsible for this division is headed

$4 \quad$ The idea for this research was inspired by J.P. Fokkelman. By applying the principles of close reading he was able to demonstrate, in many publications since the 1970s, the use of compositional devices in the Hebrew Bible and their effect on interpretation. See for example, Fokkelman 1981-1993. 
by an Old Javanese word meaning 'as it happened', kāwit:

beginning: Now there was a certain Ekalawya, the son of Hiranyadhanuh. second part: As it happened, the Pandawas went hunting. end:

For he was the swiftest one in the art of archery.

(See sentence 8.) The word kāwit is used regularly in the Adiparwa to signal a turn in a story. For example, the goddess Gangga's running across the Basus - a class of gods - is a happy coincidence as it is the beginning of the end of her curse; the unintended encounter is introduced by the word käwit. In another passage Pandu's stumbling upon a white deer will soon bring about a curse that eventually leads to his untimely death; his spotting of the animal is preceded by the word kāwit.

This way the story of Ekalawya is effectively divided into two episodes. The first episode, up to käwit, shows Ekalawya's problem and his solution, while the second episode, from käwit to the end, shows why his solution is in fact a problem and how that problem is solved.

\section{EPISODE 1}

A spectacular moment in episode 1 is when Ekalawya becomes an accomplished bowman without attending the classes of Drona. No less spectacular is how he does this: by creating a replica of his venerated teacher to make him reach his goal, his manggala, his 'source of success' as it is called in the text.

The information of episode 1 is conveyed in seven sentences. The first six of these seven sentences can be arranged in two groups of three sentences on the basis of the organizing principle of equivalence. Equivalence or parallelism refers to a correspondence of content in a couple of successive sentences; variation draws the attention to something of importance (Fowler 1996: 97ff. In studies on Indonesian literatures the term "parallelism" is reserved for parallel terms in paired lines. See Fox 1971). In the present case the meaning of the first three sentences is reflected in the next three sentences, while the seventh sentence is different. The text reads:

1 Now there was a certain Ekalawya, the son of Hiranyadhanuh.

2 He wanted to study with Drona,

3 but look! he was not accepted by him as he was the son of a Nișāda. ${ }^{5}$

4 He made a reproduction of Drona,

5 his manggala in mastering bowmanship.

6 Hence he became skilled through his dedication to his teacher.

7 Wimokșādānasandhāne. He knew how to draw an arrow and how to put it on, and how to release it. 
Lines 1-3 inform us in three steps about Ekalawya's problem, lines 4-6 inform us in three steps about his solution. The equivalence appears from the order and content of the steps: specified for each line, mention is made in the first group of father, study and outcome, in the second group of idol, study and outcome; the initial lines 1 and 4 introducing the protagonist tell us who he is and what he does, respectively. The line by line equivalence of content is supported by linguistic equivalence: the pronominal reference to the protagonist in line 4 corresponds with the low status indicated in line 1; the hope for profit in line 2 is expressed by the Old Javanese word ahyun 'to wish', and in line 5 by manggala 'source of success'; the connection between Ekalawya's efforts and the outcome is made explicit by a word for 'because' or 'because of' (apan in line 3, dening in line 6). The equivalence is further enhanced by other correspondences, such as the use of words announcing a conclusion in lines 3 (nda 'look!') and 6 (mogha 'hence').

How does our interpretation profit from this analysis? Looking at sentences 1-6, against the background of overall similarity in sentences $1 / 4$ and 2/5, it is the contrastive nature of the results in sentences $3 / 6$ that stands out. So, notwithstanding the spectacular character of Ekalawya's manggala and his ability to manage for himself, the conclusion must be that dedication to one's teacher is the key concept of this part of the text.

Sentence number 7 falls outside the above plan in several ways. To begin with, numerically there is no room for it in a system of threes. Moreover, its content does not fit into the equivalence of sentences 1-6. It sums up the results of Ekalawya's training, a topic not touched on in the preceding lines. Also, in addition to its odd position and deviating content, it betrays a different style of wording. While in sentences 1-6 economy is the norm - only basic information is given, in the shortest possible way - sentence 7 indulges in details. The insertion of a Sanskrit expression, finally, while seemingly serving no clear purpose, is another sign of its unique position (see the phrase in italics in the text). From it Ekalawya emerges as an expert. However, the purport of this detailed information is not yet clear.

\section{EPISODE 2}

The second episode focuses on Arjuna. He witnesses the extraordinary skill of Ekalawya, he is informed about Drona's share in Ekalawya's excellent performance, and eventually he is restored to his former pre-eminent position. This episode starts with sentence 8 (which at the same time demarcates the border between episodes 1 and 2) and continues until sentence 32; in all twentyfive sentences. Sentence 33 is the concluding sentence of the whole story.

Like episode 1, episode 2 is also organized in a systematic way with the help of smaller units. However, the division is based on other principles than in episode 1 . Whereas the sentences of episode 1 were clustered into units by the force of equivalence, in episode 2 the borders between the units are drawn with the help of particular sentences. There are three such sentences, creating three smaller units. The sentences are put in final position in each unit: 
end of 1:

Arjuna was flabbergasted

end of 2:

Arjuna became sad

end of 3:

Arjuna felt relieved

These sentences by themselves do not show features that would characterize them as borders; they are only recognizable as such because of their repetitive character.

The overall division of episode 2 into three units on the basis of Arjuna's mood (flabbergasted - sad - relieved) shows the state of mind of the hero as it develops from recognition via diagnosis to solution.

Unit 1, "recognition", consists of six sentences. Here, the principle of equivalence is at work again, allowing for a subdivision into two smaller units 1.1 and 1.2 of three sentences each. Unit 2, "diagnosis", contains three sentences.

Unit 3, "solution", is much larger than units 1 and 2: it numbers no fewer than sixteen sentences. Analysis of unit 3 shows that here also groups of three sentences can be distinguished. Two of these groups consist of three sentences, two other groups contain three core sentences surrounded by sentences that serve to indicate the borders of these groups. The sentences indicating the borders are standard expressions for opening and closing direct speech:

17 He said to Drona:

21 Such were the words of Arjuna.

25 Drona spoke:

29 Such were the words of Drona.

The groups with and those without explicit borders alternate (which makes explicit borders of their own superfluous in the second case). The first ones contain direct speech, the latter continue the narration.

\section{UNITS 1, 2, AND 3}

The first unit of episode 2 reads:

8 As it happened, the Pandawas went hunting.

9 There was a dog

10 that barked at Ekalawya.

11 It was shot by him;

12 its snout was full of arrows.

13 Arjuna was flabbergasted looking at it.

We are not told why Arjuna is flabbergasted. Leaving aside unlikely candidates like a dog that starts barking or a target being hit or a non-Aryan person materializing from the bush, I think Arjuna is flabbergasted because of the rapidity of Ekalawya's shooting. One moment the dog is shot, the next moment its mouth is full of arrows, so the text informs us. Such an accomplishment would impress any onlooker. Imagine the process of shooting arrows (hitting the mouth of a barking dog at the right moment is another problem, as the 
observation of barking dogs teaches us): one has to draw an arrow, put it in place against one's bow, pull the cord, aim, and let the arrow go. Shooting one arrow takes time, let alone a whole bunch of arrows. Ekalawya releases a whole bunch, filling the mouth of the dog in the twinkling of an eye. This is the reason why Arjuna is flabbergasted.

Now we understand the redundancy of sentence 7 in episode 1 (" $\mathrm{He}$ knew how to draw an arrow and how to put it on, and how to discharge it"). The quality that made Ekalawya's skill extraordinary was his rapidity. It is with regard to this quality that Arjuna has to acknowledge the superiority of Ekalawya. Sentence 7 enables the reader to know the nature of Arjuna's stupefaction.

The second unit of episode 2 reads:

14 He asked where Ekalawya had acquired his bowmanship.

15 Ekalawya told him that he was a follower of Drona.

16 Arjuna became sad, because he thought that he was the best.

Arjuna does not know Ekalawya's background, so he inquires about the origins of Ekalawya's extraordinary skill. The answer is devastating.

"To be a follower of" is a rendering of Old Javanese "worshipped by", which is an indirect yet common way of indicating the subject of a king, the wife of a husband, the student of a teacher. Ekalawya may have preferred it over frankly calling himself a student, which would have been a lie. The subtlety was lost on Arjuna as we shall see in the next unit, the first sub-unit of 3 .

\section{Unit 3.1}

The third unit of episode 2 comprises four sub-units, each consisting of (a core of) three lines. The solution of Arjuna's problem being complicated requires four sub-units: all three players in a sub-unit of their own first define their position in relation to the others before the solution is reached in the final sub-unit.

The first sub-unit has:

17 He said to Drona:

18 "By your leave, my lord,

19 I am supposed to be unrivalled in the art of archery.

20 You lied because you have a pupil who lives in the forest, who is called Ekalawya, who as a matter of fact is better than me."

21 Such were the words of Arjuna.

Why not kill Ekalawya, or challenge him, or face it and train harder; why, by all means, complain like a child? The answer must be: because superiority is not the issue. Arjuna decides to see Drona because what is at stake is the 
relationship between him and his teacher. Ekalawya's answer touches the foundation of his existence; his teacher is of overriding importance. The relationship of teacher and pupil is based on mutual trust: a teacher should be reliable, a pupil should be devoted without reserve. Both values are expressed in our story. The ideal attitude of the pupil was illustrated by Ekalawya a few lines ago, in the first episode, where it was said that the secret of his success was his loyalty to his teacher (sentence 6: "Hence he became skilled by his dedication to his teacher." The Old Javanese uses the word bhakti). The ideal attitude of the teacher is the topic of the present passage. It is expressed the reverse way, when Drona is accused by Arjuna of being unreliable (sentence 18: "You lied").

The directness of these words is shocking. We might want to ascribe it to the disturbance caused by Arjuna's bitter disappointment, or to the clumsiness of the eager youth that he is. But the set-up and the wording of Arjuna's accusation show that we are not dealing with the spontaneous outburst of an angry lad who fails to control his feelings, but with a well-built and therefore well-considered charge of low miserableness. Rhetorically, Arjuna delivers an impeccable speech.

His opening statement is a reference to Drona's gift, polite and soft: "by your leave" instead of "hey!", "your servant" rather than "I"; "I am supposed to be" instead of "it was you who called me", "without equal", not: "the best". Even the simple "bowmanship" used everywhere else in the text is replaced by the loftier "art of archery". All the sharper is the sudden charge thrown in Drona's face without any warning in the next sentence, bolstered by a set of water-tight arguments fired at Drona like the bullets of a machine-gun: "you lied", you do have someone else, don't deny because I know who he is and where he lives - ending in the climax "who is definitively better than me".

Drona could have pointed out that Arjuna is mistaken. After all, Ekalawya was not and never had been his student, so he could not be held responsible for Ekalawya's deeds. But apparently he feels urged to remove the cause of Arjuna's dismay.

\section{Unit 3.2}

Sub-unit 3.2 brings all three characters of the story together, Drona, Arjuna, and Ekalawya:

22 Drona remembered Ekalawya, whom he had declined at the time.

23 He went to him, together with Arjuna.

24 When he had arrived there, Ekalawya made an obeisance, offering himself on the basis of being a student from Drona's point of view.

It is the first and also the last time that explicit mention is made of travelling. People have been moving around before: Ekalawya went to Drona and back, the Pandawas went to the forest, Arjuna went back to see Drona, but their travelling was passed over in silence. Drona's travelling is given attention, even extensively, with no less than four words: "went" (lumampah), "coming" 
(mara), "accompanied by" (makering), "having arrived" (satěkanira). Why this emphasis? I think it has to do with Ekalawya's share in the immanent solution. Once Drona had decided on action there were two possibilities: either summon Ekalawya, or go to Ekalawya instead. By going to Ekalawya Drona shows that he has no claim on Ekalawya; the reader should realize that whatever the outcome may be it will be Ekalawya's choice.

To Ekalawya the visit of the idolized guest must have been like a heavensent present. The sentence with which he presents himself shows the wriggling it took him to steer a safe course between lie and long-felt wish. It is an odd construction, in which he calls himself a student and yet does not. What he probably does not realize is that he just laid the basis for a fatal dilemma he will be exposed to before long.

\section{Unit 3.3}

Drona reacts:

25 Drona spoke:

26 "Yadi śisyo' si me putra. My child Ekalawya!

27 If you really are my pupil, then give me your teacher's fee, forward your fee to me.

28 Your right thumb, that is what you should give to me."

29 Such were the words of Drona.

Drona's order if carried out will put an end to Ekalawya's superiority as a bowman. If carried out: it is up to Ekalawya to choose whether he wants to be Drona's student or not. The condition is awful. The Old Javanese has a pun here, not visible in my translation: daksina means "fee" but also "right" (as opposed to left. See Zoetmulder 1982 s.v.). Of course "right" refers to "right thumb", as becomes fully clear in the next sentence, when Drona says straight away "your thumb at the right side". One wonders whether this is the right time for playful niceties. Other occasions in the Adiparwa as troublesome as the present one do also sometimes involve puns, in the case of curses connecting offence and infliction. For example, a girl called Dewayānī is cursed in her future marriage to have her servant as a co-wife (makamarwa) because of her ambiguous love (makāma rwa; Juynboll 1906: 77). But Drona's request is not a curse. I do not for now know what is behind his play on words.

In a way Ekalawya gets back what he has done to others. As the dog was wounded and disabled by him, so he is now disabled by Drona.

For whom or for what the Sanskrit phrase is meant Drona starts addressing Ekalawya with? It seems unlikely in the context of the story that Ekalawya would have knowledge of classical languages. Was it meant to impress him? Showing off one's learning is one of the possible functions Zoetmulder sees for the Sanskrit fragments found in the Old Javanese parwas (Zoetmulder 1974: 90). Or - another possible function; see Zoetmulder (1974: 91) - did Drona wish to underline the sacred character of what he was going to say?

Drona by his speech to Ekalawya settles the problem of Arjuna's superiority. 
He also removes any misunderstanding about his own position as a teacher: he is not only the source of knowledge for his students, but he also decides on their progress.

\section{Unit 3.4}

The last sub-unit of unit 3 reads:

30 Ekalawya cut his fee, his thumb,

31 and offered it to Drona.

32 Arjuna felt relieved.

At last Ekalawya's goal to be accepted as a student by Drona is within reach, so it seems. But how different from what he must have imagined! The very condition for acquiring the long-desired status makes it meaningless at the same time. Ekalawya will either be a pupil of Drona but not an archer, or he will be the best archer in the world but not a pupil of Drona. In view of his choice it is clear that for Ekalawya the bhakti of a student for his master outweighs all.

Another conclusion must be that access to education after all is possible even for members of low castes.

\section{CONCLUDING REMARKS}

The story of Ekalawya in spite of its modest size shows an intricate textual organization. We come across outer borders isolating the text of the story from the surrounding text; internally, there are divisions at different levels. Various means are used to different ends: typical phrases for set functions, unmarked phrases made to function as borders by repetition, and equivalence of a literary and a linguistic nature. While our reading profits from the lucid structure our interpretation is also guided by it, through accentuation or contraposition. This way, the main topic of the conflict between dharma and loyalty stands out while other elements that play a crucial role like honesty and devotion or the difference between Ekalawya and Arjuna become sufficiently clear.

The purpose of this article was to illustrate the means and devices available for the construction of a narrative prose text in Old Javanese of around the year AD 1000, the Adiparwa. Such research was never undertaken before and was for a long time quite unlikely to be undertaken in view of the low status of the Old Javanese parwas as literary texts. Concentrating on a short story of less than one page the richness of devices that became manifest already within such a limited range was astonishing. One wonders what else might come to light once the research will be extended to other parts of the Adiparwa and to the text as a whole. I have the impression that the various stories of the Adiparwa are not the same in this respect but that there is room for different ways of textual organization. Similarly, turning to the other parwas that made their way into Old Javanese literature, it appears that the principles at work in the Wirataparwa, for example, are completely different (Van der Molen 1997, 2016). It is this intriguing variety that calls for further research on the compositional devices of these works. 


\section{APPENDIX 1}

\section{Story of Ekalawya. Old Javanese text. Adiparwa, edition Juynboll 1906, pages 129-130}

\section{EPISODE 1}

unit 1 1. Hana ta sang Ekalawya ngaranya, anak sang Hiranyadhanuh.

2. Ya tāhyun mangajya ri ḍang hyang Drona,

3. ndā tan tinanggapnirāpan Nișādaputra.

unit 2 4. Magawe ta ya Dronapratima,

5. manggalanyān pangabhyāsa dhanurweda.

6. Mogha ta widagdha dening bhaktinya ring guru.

end 7. Wimokṣādānasandhāne. Wruh dening mangalap hrü, manihangakĕn, wruh manglĕpasakĕn.

\section{EPISODE 2}

unit 1.1 8. Kawit pwa sang Pāṇdawa maburu.

9. Hana ta asu

10. umalup ikang Ekalawya.

unit 1.2 11. Pinanahnya ta ya.

12. Hibĕkan tutuknya dening hrū.

13. Kapühan ta sang Arjuna n ton i ya.

unit 2 14. Matakwan ta sira sangkanikang dhanurweda.

15. Mawarah ta sang Ekalawya, an dang hyang Drona sinĕmbahnya.

16. Manastāpa ta sang Arjuna, apan kalěwihan hiḍ̆pnira ry awaknira.

unit 3.1 17. Mājar ta sire dang hyang Drona:

18. "Sojar mpungku,

19. pinakanghulun sinangguh tan papaḍeng dhanurdharaśästra.

20. Adwā rahadyan sanghulun, apan hana śisya mpungku tamolah ring alas, mangaran Ekalawya, prasiddha lěwih sangke nghulun."

21. Mangkana ling sang Arjuna.

unit 3.2 22. Mengĕt ta dang hyang Drona ring Ekalawya, sang tinulaknirekana.

23. Lumampah ta sira mareri ya, makering sang Arjuna.

24. Satĕkanireri ya, manĕmbah ta sang Ekalawya, umarpan̄äkĕn awaknya n śișa parĕnahnira.

unit 3.3 25. Mojar ta dang hyang Drona:

26. "Yadi śișo' si me putra. Anaku sang Ekalawya!

27. Yan tuhu kita śișa mami, t agawe ta kita gurudakșina, humarěpakna mami dakșinanta.

28. Anggușțanta ri těngĕnan, yekā pawehanta kami."

29. Mangkana ling dang hyang Drona. 
unit 3.4 30. Tinugĕlnya ta dakșinānggusțanikā,

31. sinĕmbahakĕnya ri ḍang hyang Droṇa.

32. Enak tāmběk sang Arjuna.

end 33. Sira ta lěwih läghawanireng dhanurweda. 


\section{APPENDIX 2}

\section{Story of Ekalawya. English translation.}

\section{EPISODE 1}

unit 1 1. Now there was a certain Ekalawya, the son of Hiranyadhanuh.

2. He wanted to study with Drona,

3. but look! He was not accepted by him, as he was the son of a Nișāda.

unit $24 . \quad$ He made a reproduction of Drona,

5. his manggala in mastering bowmanship.

6. Hence he became skilled through his dedication to his teacher.

end 7. Wimokșādānasandhāne. He knew how to draw an arrow and how to put it on, and how to release it.

\section{EPISODE 2}

unit 1.1 8. As it happened, the Pandawas went hunting.

9. There was a dog

10. that barked at Ekalawya.

unit 1.2 11. It was shot by him;

12. its snout was full of arrows.

13. Arjuna was flabbergasted looking at it.

unit 2 14. He asked where Ekalawya had acquired his bowmanship.

15. Ekalawya told him that he was a follower of Drona.

16. Arjuna became sad, because he thought that he was the best.

unit 3.1 17. He said to Drona:

18. "By your leave, my lord,

19. I am supposed to be unrivalled in the art of archery.

20. You lied because you have a pupil who lives in the forest, who is called Ekalawya, who as a matter of fact is better than me."

21. Such were the words of Arjuna.

unit 3.2 22. Drona remembered Ekalawya, whom he had declined at the time.

23. He went to him, together with Arjuna.

24. When he had arrived there, Ekalawya made an obeisance, offering himself on the basis of being a student from Drona's point of view.

unit 3.3 25. Drona spoke:

26. "Yadi śisyo' si me putra. My child Ekalawya!

27. If you are really my pupil, then give me your teacher's fee, forward your fee to me.

28. Your right thumb, that is what you should give to me."

29. Such were the words of Drona.

unit 3.4 30. Ekalawya cut his fee, his thumb,

31. and offered it to Drona.

32. Arjuna felt relieved.

end $\quad 33$. He, then, was the swiftest one in bowmanship. 


\section{REFERENCES}

Fokkelman, J.P. 1981-1993. Narrative art and poetry in the Books of Samuel. A full interpretation based on stylistic and structural analyses. Assen: Van Gorcum. 4 vols.

Fowler, Roger. 1996. Linguistic criticism. Second edition. Oxford, New York: Oxford University Press.

Fox, James J. 1971. "Semantic parallelism in Rotinese ritual language”, Bijdragen tot de Taal-, Land-en Volkenkunde 127: 215-255.

Juynboll, H.H. 1906. Âdiparwa; Oudjavaansch prozageschrift, uitgegeven. 's-Gravenhage: Nijhoff.

Molen, Willem van der. 1997. "Kedudukan sastra karya Jawa Kuno Wirataparwa", in: Sri Sukesi Adiwimarta [and others] (eds), Pendar pelangi; Buku persembahan untuk Prof. Dr. Achadiati Ikram, pp. 241-259. Jakarta: Fakultas Sastra Universitas Indonesia and Yayasan Obor Indonesia.

Molen, Willem van der. 2016. Love and hatred in Old Javanese literature; The story of Kaca and Dewayani. [Solo:] Universitas Sebelas Maret. [Foundation Day Speech.]

Robson, S.O. 1983. "Kakawin reconsidered; Toward a theory of Old Javanese poetics", Bijdragen tot de Taal-, Land-en Volkenkunde 139: 291-219.

Zoetmulder, P.J. 1974. Kalangwan; A survey of Old Javanese literature. The Hague: Nijhoff. [KITLV Translation Series 16.]

Zoetmulder, P.J. (with the collaboration of S.O. Robson). 1982. Old JavaneseEnglish dictionary. 's-Gravenhage: Nijhoff. 2 vols. 